\title{
Scale-up considerations for monoclonal antibody production process: an oxygen transfer flux approach
}

\author{
Laura Gimenez*, Claire Simonet, Laetitia Malphettes \\ From 23rd European Society for Animal Cell Technology (ESACT) Meeting: Better Cells for Better Health \\ Lille, France. 23-26 June 2013
}

\section{Background}

When scaling up a monoclonal antibody (mAb) production process in stirred tank bioreactor, oxygen transfer is probably one of the most challenging parameters to consider. Approaches such as keeping constant specific power input or tip speed across the scales are widely described in the literature and are often based on the assumption that mammalian cells are sensitive to shear stress.

However, with the high cell densities reached in modern processes, such scale-up strategies can lead to relatively high gas flow rate to compensate low agitation speed which could be detrimental to cells in its own right.

As an alternative, we explored a scale-up strategy based on the overall oxygen transfer flux (OTF) required by the cell culture process. OTF was defined as directly proportional to oxygen transfer coefficient $\left(\mathrm{k}_{\mathrm{L}} \mathrm{a}\right)$ and oxygen enrichment in the gas mix. This way the overall gas flow can be kept at relatively low values, while satisfying the oxygen requirements of a high cell density culture.

\section{Materials and methods}

Process scale-up between 3 different stirred tank bioreactors was studied: a $2 \mathrm{~L}$ glass bioreactor (Sartorius Stedim Biotech) equipped with one 3-segment blade impeller, a $10 \mathrm{~L}$ glass bioreactor (Sartorius Stedim Biotech) equipped with two 3-segment blade impellers and a $80 \mathrm{~L}$ stainless steel bioreactor (Zeta Biopharma) equipped with two elephant ear impellers.

Oxygen transfer coefficients $\left(\mathrm{k}_{\mathrm{L}} \mathrm{a}\right)$ were determined for the chemically defined production medium, using the dynamic technique of oxygen adsorption. The statistical analysis software JMP (SAS) was then used in order to

* Correspondence: Laura.Gimenez@ucb.com

BioTech Sciences, UCB Pharma SA, Braine I'Alleud, Belgium express $k_{\mathrm{L}} \mathrm{a}$ 's according to the following equation: $\mathrm{k}_{\mathrm{L}} \mathrm{a}=$ $\mathrm{A} *(\mathrm{P} / \mathrm{V}){ }^{\alpha} * \mathrm{Vs}^{\beta}, \mathrm{P} / \mathrm{V}$ being volumetric power input $\left[\mathrm{W} . \mathrm{m}^{-3}\right]$ and Vs being superficial air velocity $\left[\mathrm{m}^{-\mathrm{s}^{-1}}\right]$, and to analyze our results.

Oxygen transfer flux was defined as followed: OTF = $\mathrm{k}_{\mathrm{L}} \mathrm{a} *\left(\% \mathrm{O}_{2}\right.$ in the gas mix $/ \% \mathrm{O}_{2}$ in air $)$.

For cell culture experiments, bioreactors were inoculated with a $\mathrm{CHO}$ cell line producing a mAb. Cells were cultivated in chemically defined media for a 14-day fed-batch process. The culture was controlled to maintain the desired process parameters (temperature, $\mathrm{pH}, \mathrm{dO}_{2}$ and glucose concentration). $\mathrm{dO}_{2}$ level was maintained using a cascade aeration. Viable cell density (VCD) and viability were monitored by Trypan blue dye exclusion using a Vicell XR (Beckman Coulter). Glucose and lactate concentrations were determined using a Nova Bioprofile 400 analyzer (Nova Biomedical). Offline dissolved $\mathrm{CO}_{2}$ and osmolality were measured with a Nova Bioprofile pHox (Nova Biomedical) and Osmo 2020 (Advanced Instrument) analyzers respectively. $\mathrm{mAb}$ concentrations were determined by Protein A HPLC.

Table 1 Determination of aeration and agitation strategy in the $80 \mathrm{~L}$ bioreactor, based on the maximum OTF required by the cells at $2 L$ and $10 L$ scales.

\begin{tabular}{|c|c|c|c|c|}
\hline & $2 \mathrm{~L}$ & $10 \mathrm{~L}$ & & $80 \mathrm{~L}$ \\
\hline $\mathrm{P} / \mathrm{V}\left[\mathrm{W} \cdot \mathrm{m}^{-3}\right]$ & 30 & 69 & & 80 \\
\hline Vs $\left[\times 10^{-4} \mathrm{~m} \cdot \mathrm{s}^{-1}\right]$ & 0.94 & 3.53 & & 4.03 \\
\hline $\mathrm{k}_{\mathrm{L}} \mathrm{a}\left[\times 10^{-3} \mathrm{~s}^{-1}\right]$ & 0.70 & 1.43 & & 3.85 \\
\hline$\% \mathrm{O}_{2}$ in gas mix & 74 & 90 & & 30 \\
\hline OTF $\max \left[\times 10^{-3} \mathrm{~s}^{-1}\right]$ & 2.44 & 6.11 & $\begin{array}{c}\text { Target OTF for } 80 \mathrm{~L} \\
=10 \mathrm{~L} \text { OTF } \\
\rightarrow\end{array}$ & 5.55 \\
\hline
\end{tabular}



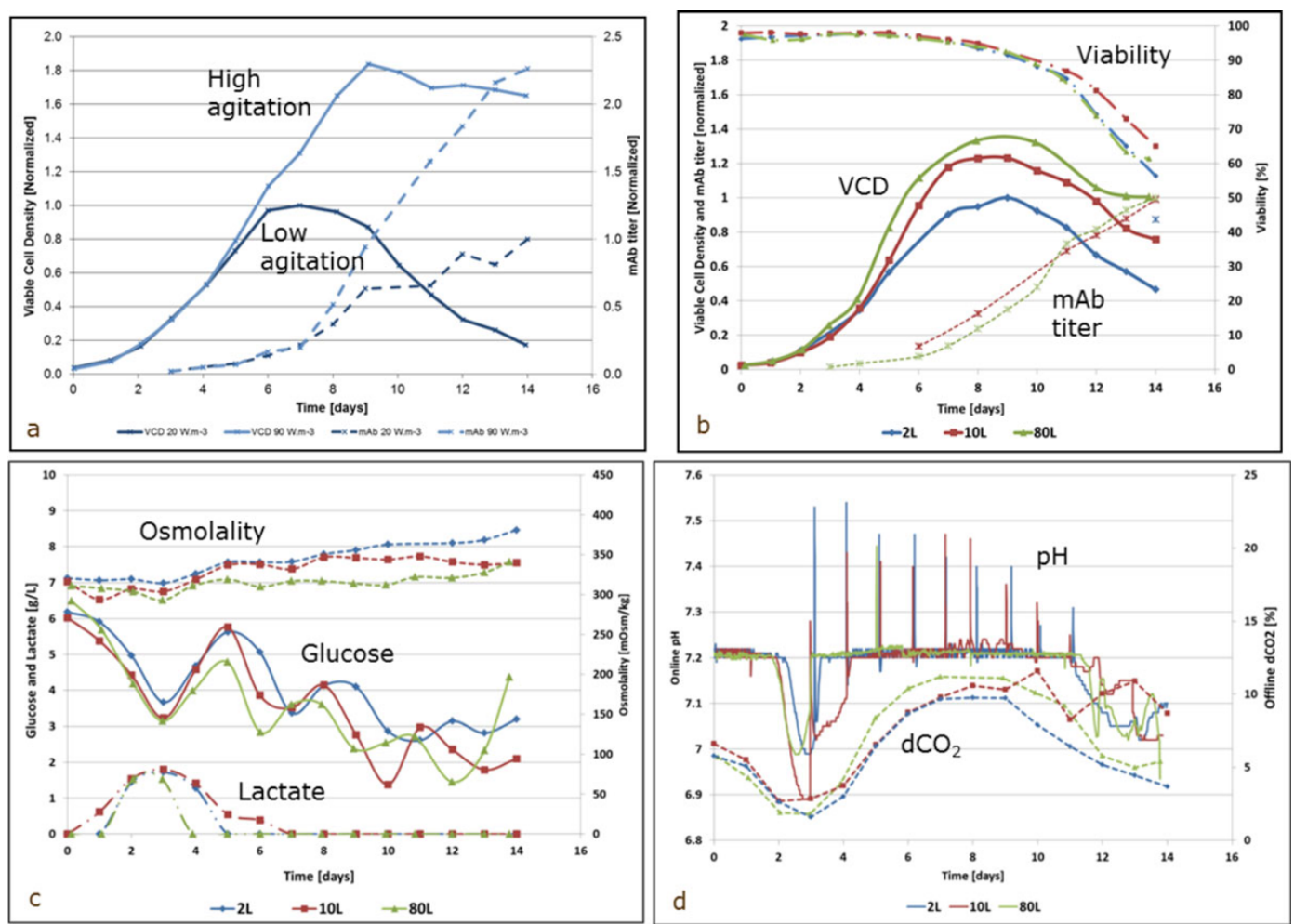

Figure 1 Cell culture process performance at $\mathbf{2} \mathbf{L}, \mathbf{1 0} \mathrm{L}$ and $\mathbf{8 0 ~} \mathrm{L}$ scale. a) Impact of agitation speed on VCD and mAb titer at $2 \mathrm{~L}$ scale. b) Comparison of VCD, viability and mAb titer obtained in $2 \mathrm{~L}, 10 \mathrm{~L}$ and $80 \mathrm{~L}$ bioreactors. c) Comparison of osmolality, glucose and lactate profiles obtained in $2 \mathrm{~L}, 10 \mathrm{~L}$ and $80 \mathrm{~L}$ bioreactor. d) Online pH and dCO levels obtained in $2 \mathrm{~L}, 10 \mathrm{~L}$ and $80 \mathrm{~L}$ bioreactors.

\section{Results}

$\mathrm{k}_{\mathrm{L}}$ a mapping of $2 \mathrm{~L}, 10 \mathrm{~L}$ and $80 \mathrm{~L}$ bioreactors

The $2 \mathrm{~L}$ and $10 \mathrm{~L}$ bioreactors were characterized for a range of superficial gas velocity going from $5.0 \times 10^{-5}$ to $4.0 \times 10^{-4} \mathrm{~m} . \mathrm{s}^{-1}$ and the $80 \mathrm{~L}$ for a range going from $2.0 \times 10^{-4}$ to $1.2 \times 10^{-3} \mathrm{~m} . \mathrm{s}^{-1}$. Specific power input was ranged from 10 to $90 \mathrm{~W} . \mathrm{m}^{-3}$ for the $2 \mathrm{~L}$ bioreactor, 20 to $130 \mathrm{~W} \cdot \mathrm{m}^{-3}$ for the $10 \mathrm{~L}$ bioreactor and 5 to $80 \mathrm{~W} \cdot \mathrm{m}^{-3}$ for the $80 \mathrm{~L}$ bioreactor. Models were generated with JMP and gave the following equations for $\mathrm{k}_{\mathrm{L}} \mathrm{a}\left[\mathrm{s}^{-1}\right]$ :

2 L bioreactor: $\mathrm{k}_{\mathrm{L}} \mathrm{a}=6.37 \times 10^{-2} *(\mathrm{P} / \mathrm{V})^{0.28 *} \mathrm{Vs}^{0.59}$ $\left(\mathrm{R}^{2}=0.98\right.$, Prob $\left.>\mathrm{F}:<0.0001\right)$

10 L bioreactor: $\mathrm{k}_{\mathrm{L}} \mathrm{a}=4.07 \times 10^{-2} *(\mathrm{P} / \mathrm{V})^{0.55 * \mathrm{Vs}^{0.67}}$ $\left(\mathrm{R}^{2}=0.91\right.$, Prob $\left.>\mathrm{F}:<0.0001\right)$

80 L bioreactor: $\mathrm{k}_{\mathrm{L}} \mathrm{a}=5.53 \times 10^{-2} *(\mathrm{P} / \mathrm{V})^{0.72 * \mathrm{Vs}^{0.77}}$ $\left(\mathrm{R}^{2}=0.92\right.$, Prob $>$ F: $\left.<0.0001\right)$

\section{Scale-up of aeration and agitation strategy of a monoclonal antibody production process using a constant OTF approach}

The cell culture process was initially developed at $2 \mathrm{~L}$ and $10 \mathrm{~L}$ scale. Maximum Oxygen Transfer Flux was determined at maximum cell density for these two scales. This maximum OTF was kept constant for scaling up to $80 \mathrm{~L}$ (Table 1). From $\mathrm{k}_{\mathrm{L}}$ a mapping of the $80 \mathrm{~L}$ bioreactor, appropriate $\mathrm{P} / \mathrm{V}, \mathrm{Vs}$ and $\mathrm{O}_{2} \%$ values were chosen in order to reach the target OTF.

To confirm that high specific power input are well tolerated by $\mathrm{CHO}$ cells, the fed-batch process was first run in two $2 \mathrm{~L}$ bioreactors (Figure 1a). Agitation speed was set at $250 \mathrm{rpm}\left(20 \mathrm{~W} \cdot \mathrm{m}^{-3}\right)$ in the first bioreactor and at $400 \mathrm{rpm}\left(90 \mathrm{~W} \cdot \mathrm{m}^{-3}\right)$ in the second bioreactor. In the high agitation condition, the maximum VCD was 1.8 -fold higher, viability remained above $80 \%$ (versus $60 \%$ in the low agitation condition) and $\mathrm{mAb}$ titer was 2.2-fold higher.

Our model fed-batch process was then run in our $80 \mathrm{~L}$ bioreactor, using the aeration strategy defined in Table 1. Figure $1 \mathrm{~b}, \mathrm{c}$ and $1 \mathrm{~d}$ show that the process was successfully scaled-up from $2 \mathrm{~L}$ and $10 \mathrm{~L}$ to $80 \mathrm{~L}$ bioreactor.

\section{Conclusions}

Thanks to extensive characterization of aeration conditions in $2 \mathrm{~L}, 10 \mathrm{~L}$ and $80 \mathrm{~L}$ bioreactors, the oxygen transfer flux approach enabled to have a sufficient aeration and comparable process performance across the scales, including $\mathrm{dCO}_{2}$ profile. The same strategy will be 
used for further scale-up of the process to $2000 \mathrm{~L}$. However, the results also revealed that our $2 \mathrm{~L}$ scale model should be re-assessed to become more predictive of $10 \mathrm{~L}$ and $80 \mathrm{~L}$ scales.

\section{Acknowledgements}

This work was carried out within the Cell Culture Process Sciences

laboratories of UCB Pharma SA, Braine l'Alleud, Belgium.

Published: 4 December 2013

doi:10.1186/1753-6561-7-S6-P49

Cite this article as: Gimenez et al:: Scale-up considerations for monoclonal antibody production process: an oxygen transfer flux approach. BMC Proceedings 2013 7(Suppl 6):P49.

Submit your next manuscript to BioMed Central and take full advantage of:

- Convenient online submission

- Thorough peer review

- No space constraints or color figure charges

- Immediate publication on acceptance

- Inclusion in PubMed, CAS, Scopus and Google Scholar

- Research which is freely available for redistribution

Submit your manuscript at www.biomedcentral.com/submit 